\title{
Gray Zone Patients in Our Clinical Data
}

\author{
Arber Neziri $^{1, ~}{ }^{*}$, Flamur Tartari $^{2}$, Avni Fetahu $^{1}$, Liridon Selmani $^{1}$, Fahredin Veselaj $^{1}$ \\ ${ }^{1}$ Urology Clinic, University Clinical Center of Kosovo, Prishtina, Kosovo \\ ${ }^{2}$ Service of Urology, M. Tereza, Tirana, Albania
}

Email address:

arberlindialtini@hotmail.com (A. Neziri)

To cite this article:

Arber Neziri, Flamur Tartari, Avni Fetahu, Liridon Selmani, Fahredin Veselaj. Gray Zone Patients in Our Clinical Data. American Journal of Health Research. Vol. 3, No. 6, 2015, pp. 381-385. doi: 10.11648/j.ajhr.20150306.21

\begin{abstract}
Objective: To determine the relationship between the prostate volume and the serum values ofprostate specific antigen among patients in the "grey zone", classified according to their age group. Gray zone represents serum prostate specific antigen values between 4.1 to $10 \mathrm{ng} / \mathrm{ml}$. Material and Methods: Prospective and retrospective 1420 patients classified in four age-groups with LUTS (Lower urinary tract symptoms) were analyzed. Patients were treated for BPH in the urology clinical at the University Clinical Center of Kosovo during the period of January 2008 - October 2014. Data were recorded from patients according to age, prostate size estimated by transabdominal ultrasound using $3.5 \mathrm{MHz}$ ultrasonography, according to the ellipsoid formula, $\mathrm{V}=\mathrm{D} 1 \mathrm{xD} 2 \mathrm{xD} 3 / 2.5$, volume of prostate, $\mathrm{V}=\mathrm{TxAPxCCxPi} / 6$ where $\mathrm{T}=$ transverse diameter, $\mathrm{AP}=$ antero-posterior diameter, $\mathrm{CC}=$ cranial caudal diameter. Patients with confirmed prostate cancer were excluded from the study. Statistical analyses used t-test and ANOVA with 95 and 99\% confidence intervals. Results: For the grey zone patients, these mean values were $44.6 \mathrm{~cm} 3$ and $5.9 \mathrm{ng} / \mathrm{mL}$. Conclusions: The data provide evidence to support that prostate volume and serum PSA concentration significantly correlate with aging and within the grey zone patients.
\end{abstract}

Keywords: Grey Zone, Benign Prostate Hypertrophy, Prostate Specific Antigen (PSA), Volume of Prostate

\section{Background}

Benign prostate hyperplasia (BPH) disease is rare before the age of 30 years old in men. After the age of 50, the disease appears more often, and the obstructive symptoms are present in around $50 \%$ of men at the age of 75 and in $30 \%$ of men at the age of 80 at which prostatectomy intervention is required. The presence of testicular androgens and estrogens hormones are necessary in the development of the prostate in the embryo and its intensive growth until puberty.

Of all markers used in for prostate cancer screening the most important is the prostate specific antigen (PSA). As tumor markers may serve specific products of tumor cells, their metabolites including also molecular markers. Since PSA is produced by benign cells and is also found in malignant prostate cells, they certainly do not represent an ideal tumor marker. An ideal tumor marker should be strongly specific and positive only in the presence of prostate cancer and adverse to other diseases. PSA is not quite sensitive which comes from the fact that $38 \%$ to $48 \%$ of patients with intra-prostatic carcinoma have normal PSA levels.

If the upper limit of normal PSA serum levels is considered to be $4 \mathrm{ng} / \mathrm{ml}$, PSA as a prostate cancer tumor marker compared to BPH has a specificity of $49 \%$ and sensitivity of $71 \%$. Despite these shortcomings in clinical practice, PSA currently represents the best tumor marker for prostate cancer detection [7]. It is observed that PSA levels increases with age even without cancer existence. The reason for this occurrence is that the prostate volume growth is due to the development of $\mathrm{BPH}$, but also contributes to the subclinical prostatitis, ischemia, infarct of the prostate and "leakage" of PSA, which is higher in old age man.

Starting from the 5th decade of life, PSA levels rise even in the absence of prostate cancer. Its level will increase also in the next decade. Older men have higher PSA values compared to younger males [7].

Today, there is a large number of tests for the PSA assessment, among them of which the most common is the Tandem R, where $100 \%$ of healthy people younger than 40 years and $97 \%$ of healthy people older than 40 years having PSA values up to $4.0 \mathrm{ng} / \mathrm{ml}$. The examined persons older than 40 years do not have the PSA value above $10 \mathrm{ng} / \mathrm{ml}$ [8].

Similar to this test, there is the tandem E test which differs from the previous one where, instead of radioactive antibodies, alkaline phosphatase enzyme associated with the 
antibody is used, even when normal values for this test are 0 to $4 \mathrm{ng} / \mathrm{ml}$ [7].

PSA "gray zone "represents serum PSA values between 4.1 to $10 \mathrm{ng} / \mathrm{ml}$. It is named gray zone because the cause of serum PSA levels to increase may be due to different clinical conditions such as prostate cancer, $\mathrm{BPH}$, prostatitis, ischemia and prostate infarct as well as various changes caused by age. To distinguish the causes of high serum PSA levels from prostate cancer, in clinical practice, prostate biopsy is necessary [7].

\section{Materials and Methods}

Prospectively and retrospectively 1420 patients with LUTS (Lower Urinary Tract Symptoms) were analyzed. Patients were treated for BPH in the University Clinical Center of Kosovo - Urology Clinic, during the period of time: January 2008 - October 2014. Research involving human subjects that is reported in the manuscript has been approved by the local ethical commission board from the University of Prishtina. Research carried out on humans was in compliance with the Helsinki Declaration.

Consent for participation in the study was obtained from participants. Data recorded from patients: age, prostate size estimated by transabdominal ultrasound using $3.5 \mathrm{MHz}$ sonde, according to the ellipsoid formula, where $\mathrm{V}=$ $\mathrm{D} 1 \mathrm{xD} 2 \mathrm{xD} 3 \backslash 2.5$ or Volume of prostate formula $=$ TxAPxCCxPi $\backslash 6$ where $\mathrm{T}=$ transverse diameter, AP = Antero-posterior diameter, $\mathrm{CC}=$ cranial caudal diameter. Also a digito-rectal (DRE) examination of prostate was performed. In cases suspected for prostate malignity ultrasound guided biopsy was performed.

Patients in which prostate cancer was confirmed were excluded from the study.

PSA values were calculated using IRMA method (Immunoradioassay) monoclonal antibodies were obtained by a manufacturing company. The manufactured product is IMMUNOTECH - manufacturing company (Czech Republic). Laboratory analysis was conducted at the Institute of Physiology and Immunology in UCCK in Pristina. Determination of PSA levels was based on the use of two different types of mouse monoclonal antibodies. Samples of serum or plasma were placed in test tubes incubated with monoclonal antibodies, which were present in the inner wall of the tube, in the presence of a second monoclonal antibody, which was marked with J125. After incubation the content of the test tube was washed so that antibodies tagged with J125 are left and not connected. Afterwards radioactivity was detected with gamma meters. These values are determined by a standard curve. Total PSA concentration in sample is proportional to the radioactivity. Radioactivity was measured by gamma radiation meter type DPC.

The concentration of total PSA in the range of 146 healthy people is determined by this method. PSA average concentration was $0.77 \mathrm{ng} / \mathrm{ml}$ with a standard deviation of $0.76 \mathrm{ng} / \mathrm{ml} .95 \%$ of the samples had total PSA below 1.8 $\mathrm{ng} / \mathrm{ml}$, and $99 \%$ of samples below $4.2 \mathrm{ng} / \mathrm{ml}$.
Statistical parameters were calculated for the index of structure, the arithmetic average, standard deviation, minimum and maximum values, as well as linear correlation. Statistical analyses used t-test and ANOVA with 95 and $99 \%$ confidence intervals.

\section{Results}

The research included 1420 patients with benign prostate hyperplasia.

The average age of the patients involved in the research was 67.33 years old (standard deviation \pm 8:07 years). The youngest patient with benign prostate hyperplasia was 50 years old and the oldest 87 years old. Divided by age group, the largest number of patients 670 , or $47.2 \%$ belonged to the age group 60-69 years old and 420 patients, or $29.6 \%$ to the age group 70-79 years old, 210 of them, or $14.8 \%$ to the age group 50-59 years and 120 patients, or $8.5 \%$ of the age group 80-89 years (Tab. 1 and Figure 1).

Table. 1. Patients included in the survey classified by age group.

\begin{tabular}{lll}
\hline Age group & N & \% \\
\hline $50-59$ & 210 & 14.8 \\
$60-69$ & 670 & 47.2 \\
$70-79$ & 420 & 29.6 \\
$80-89$ & 120 & 8.5 \\
Total & 1420 & 100.0 \\
Mean \pm SD ( vjet ) & $67.33 \pm 8.07$ & \\
Range & $50-87$ years & \\
\hline
\end{tabular}

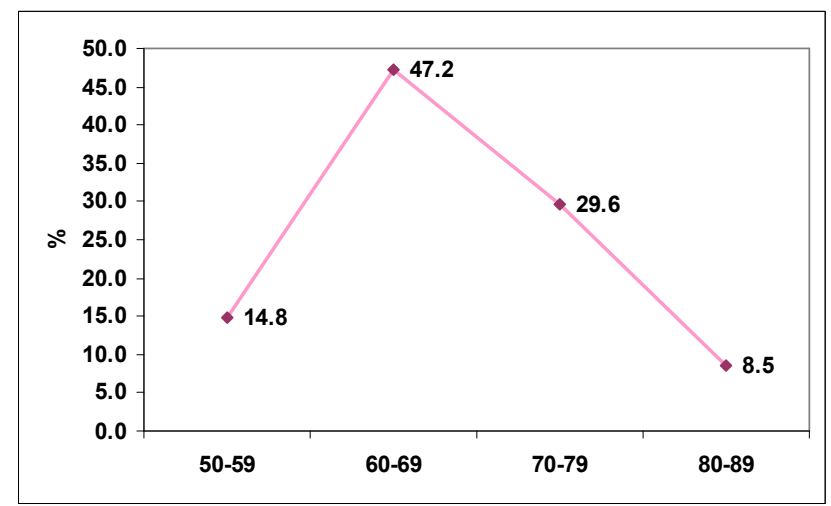

Fig. 1. Structure of patients according to the age group.

Table 2. Patients according to the concentration of PSA values.

\begin{tabular}{lll}
\hline PSA values & $\mathbf{N}$ & $\mathbf{\%}$ \\
\hline$<4.1 \mathrm{ng} / \mathrm{ml}$ & 1030 & 72.5 \\
$4.1-10 \mathrm{ng} / \mathrm{ml}$ & 360 & 25.4 \\
$>10 \mathrm{ng} / \mathrm{ml}$ & 30 & 2.1 \\
Total & 1420 & 100.0 \\
\hline
\end{tabular}

In our clinical material, most patients - 1030 of them, or $72.5 \%$ had serum PSA concentration below $4.1 \mathrm{ng} / \mathrm{ml}, 360$ or $25.4 \%$ of $4.1-10 \mathrm{ng} / \mathrm{ml}$ ie belong gray zone (Tab. 2 and Graf. 2). 


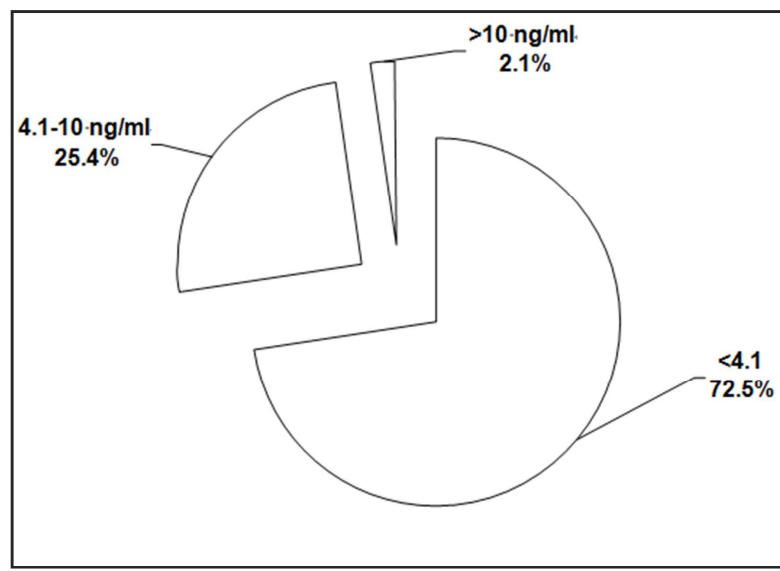

Fig. 2. Structure of patients belonging to the gray zone."

Table 3. Values of PSA and prostate volume in "ray zone"patients.

\begin{tabular}{llll}
\hline \multirow{2}{*}{ PSA Values } & \multicolumn{2}{l}{ Volume of prostate $\mathbf{c m} 3$} & \multirow{2}{*}{ T-test p-value } \\
\cline { 2 - 3 } & Mean & SD & \\
\hline$<4.1 \mathrm{ng} / \mathrm{ml} \mathrm{n}=1030$ & 36.9 & 8.2 & \multirow{2}{*}{$=4.328 \mathrm{p}<0.0001$} \\
$4.1-10 \mathrm{ng} / \mathrm{ml} \mathrm{n}=360$ & 44.6 & 11.6 & \\
\hline
\end{tabular}

Table 3. The average prostate volume of gray zone patients and patients with PSA concentration $<4.1 \mathrm{ng} / \mathrm{ml}$. The average prostate volume for gray zone patients was $44.6 \mathrm{~cm} 3$ (standard deviation $\pm 11.6 \mathrm{~cm} 3$ ), while the average prostate volume patients with PSA values $<4.1 \mathrm{ng} / \mathrm{ml}$ was $36.9 \mathrm{~cm} 3$ (standard deviation $\pm 8.2 \mathrm{~cm} 3$ ). T-test obtained a distinction with a high statistical significance between prostate volume of the two groups $(\mathrm{t}=4328, \mathrm{p}<0.0001)$.

Table 4. PSA values and age in "gray zone"patients.

\begin{tabular}{llll}
\hline \multirow{2}{*}{ PSA Values } & \multicolumn{2}{l}{ Age Years } & \multirow{2}{*}{ T-test p-value } \\
\cline { 2 - 3 } & Mean & SD & \\
\hline$<4.1 \mathrm{ng} / \mathrm{ml} \mathrm{n}=1030$ & 66.00 & 8.00 & \multirow{t}{*}{$=3.329 \mathrm{p}=0.001$} \\
$4.1-10 \mathrm{ng} / \mathrm{ml} \mathrm{n}=360$ & 71.00 & 7.00 & \\
\hline
\end{tabular}

Table 4 Shows the average age of gray zone patients and patients with PSA concentration $<4.1 \mathrm{ng} / \mathrm{ml}$. The average age of gray zone patients was 71.00 years ( \pm standard deviation 7:00years), whereas the average age of patients with PSA values $<4.1 \mathrm{ng} / \mathrm{ml}$ was 66.00 years (standard deviation \pm 8:00 years). With $\mathrm{T}$-test it is shown a distinction with high statistical age significance between patients in both groups $(\mathrm{t}=3329, \mathrm{p}<0: 01)$.

Table 5. Average prostate volumes and average values of serum PSA of gray zone patients.

\begin{tabular}{lllll}
\hline Age group & $\mathbf{N}$ & $\mathbf{\%}$ & $\begin{array}{l}\text { Volume of prostate } \\
(\mathbf{c m} 3)\end{array}$ & PSA (ng/ml) \\
\hline $50-59$ & 20 & 5.6 & 40.5 & 4.8 \\
$60-69$ & 100 & 27.8 & 40.5 & 5.6 \\
$70-79$ & 200 & 55.6 & 45.6 & 6.2 \\
$80-89$ & 40 & 11.1 & 51.3 & 7.2 \\
Total & 360 & 100.0 & 44.6 & 5.9 \\
\hline
\end{tabular}

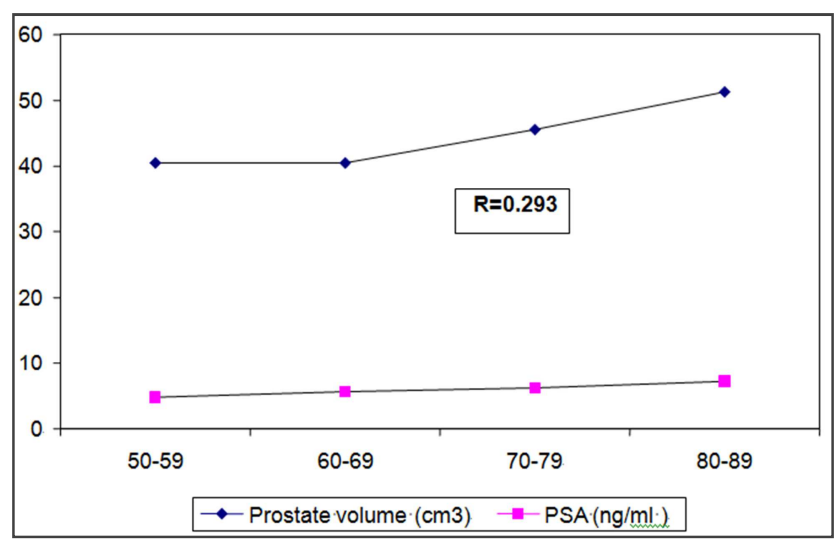

Fig. 3. Correlation between age, prostate volume and PSA value to gray zone patients.

In "gray zone" patients using a MULTIPEL correlation a positive correlation of a low level $(\mathrm{r}=0,293)$ between age, prostate volume and serum PSA values was gained. I.e. by aging - prostate and serum PSA levels increase.

\section{Discussion}

Despite the fact that PSA today is considered the leading tumor marker in prostate cancer detection, it is still far away as being an ideal tumor marker. Ideal tumor markers should be strongly specific to prostate cancer and negative to other diseases [7, 11]. in the present study, PSA does not fulfill this condition. PSA also is not very sensitive, from the fact that $38 \%$ to $48 \%$ of patients with intra-prostatic cancer have normal PSA values. Despite these shortcomings PSA is still considered the main tumor marker tool in prostate carcinoma detection $[7,9,11]$.

PSA is strongly correlated with prostate volume and age in patients with $\mathrm{BPH}$. It is proven that at the age of 60 , the incidence of $\mathrm{BPH}$ is around $60 \%$, whereas in the eighth decade approximately in $95.5 \%$ of men $\mathrm{BPH}$ is present [7, $11]$.

Increased serum PSA values except BPH and prostate cancer also affects many other factors such as urethral catheterization, acute prostate inflammation, AUR (acute urinary retention), then endourologic interventions such as cystoscopy, TUR of prostate, and prostate biopsy [4]. A correlation between AUR and PSA was determined in patients with chronic prostate inflammation [4].

PSA level above $4 \mathrm{ng} / \mathrm{ml}$ were detected in $64 \%$ of AUR patients and $38 \%$ in patients without AUR. Mean PSA levels in patients with chronic prostate inflammation in AUR was $7.75 \mathrm{ng} / \mathrm{ml}$ while in patients without AUR was $5.32 \mathrm{ng}$ $/ \mathrm{ml}[4]$.

Nadler and colleagues also suggested that prostate chronic inflammation increased PSA levels and these data were more compatible with other authors results such as Iran and colleagues who also demonstrated that inflammation in the prostate biopsy has significantly increased PSA levels as a result of damaged glandular epithelium [4].

Damage to the integrity of the prostate gland from 
inflammation may be the main cause of increased PSA values in the group with AUR (acute urinary retention).

Every pathology that damages the prostate glands leads to distribution of prostate intraluminal secretion through stromal vascular structures and thus increases serum PSA levels. For that particular reason we suggest that prostate chronic inflammation seems to play a very important role in patients with AUR as a result of $\mathrm{BPH}$ and consequently increases PSA serum levels [4].

\section{Conclusions}

The data confirms that prostate volume and PSA concentration ofserumic PSA have significant correlation and rises with aging among the "grey zone" patients.

\section{Authors Contribution}

A E. $\mathrm{N}$ made substantial contribution to conception and study design and data collection. AE. N, FT, LS, AF and FV were involved in refining the study design, statistical analysis and drafting manuscript. All authors read and approved the final manuscript.

\section{Acknowledgments}

We acknowledge support from Urology Clinic, University Clinical Center in Prishtina.

\section{References}

[1] Vesely S et al. Relationship Between Age, Prostate Volume, Prostatespecific Antigen, Symtome Score and Urofflowmetry in Men with Lower Urinary Tract Symptoms. Scand J Urol Nephrol 2003: 37: 322-328.

[2] Chung BH, Hong SJ, Cho JS et al. Relationship between serum prostate-specific antigen and prostate volume in Korean men with Benign prostatic hyperplasia:a multicentry study. BJU International 2006, 97: 742-746.

[3] Hedelin H, Johansson N, Stroberg P. Relationship between benign prostatic hyperplasia and lower urinary tract symptoms and correlation between prostate volume and serum prostaticspecific antigen in clinical routine. Scandinavian Journal of Urology and Nephrology, 2005; 39: 154-159.

[4] Kefi A, Koseoglu H, Celebi et al. Relation between acute urinary retention, chronic prostatic inflammation and accompanying elevated prostate-specific antigen. Scandinavian Journal of Urology and Nephrology, 2006; 40: 155-160.

[5] Tanagho EA, McAninch JW. Smiths General Urology. USA. Prentice-Hall International. Fourteenth edition. 1998: 8-11, 410-434.

[6] Heidennreich A, Aus G, Abbou CC et al. Guidelines on prostate Cancer. EAU, 2007 edition: 9-19.

[7] Mochtar CA, Kiemeney LA, Van Riemsdijk MM et al. Prostate -specific antigen as an estimator of prostate volume in the management of patients with symptomatic benign prostatic hyperplasia. Eur Urol, 2003 Dec: 44(6): 695-700.

[8] Marberger MJ, Andersen JT, Nickel JC et al. Prostate volume and serum prostate-specific antigen as predictors of acute urinary retention. Combined experience from three large multinational placebo-controlled trials. EUR urol, 2000 Nov: 38(5): $563-568$.

[9] Roehrborn CG, Boyle P, Gould AL et al. Serum prostatespecific antigen as a predictor of prostate volume in men with benign prostatic hyperplasia. Urology, 1999 Mar: 53(3): 581589 .

[10] Jacobsen SJ, Jacobson DJ, Girman CJ et al. Natural history of prostatism: risk factors for acute urinary retention. J Urol 1997; 158: 481-487.

[11] Boyle P, Roehrborn CG. Prostate volume predicts outcome of treatment of benign prostatic hyperplasia with finasteride: meta-analysis of randomized clinical trials.Urology1996; 48: 398-405.

[12] Roehrborn CG, Malice M, Cook TJ et al. Clinical predictors of spontaneous acute reteention in men with LUTS and clinical BPH: a comprehensiv analysis of the pooled placebo groups of several large clinical trials.Urology 2001; 58: 210-216.

[13] Roehrborn CG, Boyle P, Bergner D et al. Serum prostatespecific antigen and prostate volume predict long term changes in symptoms and flow rate; results of fouryear,randomized trial compering finasteride versus placebo.PLESS study Group. Urology 1999; 54: 662-669.

[14] Bo M, Ventura M, Marinello et al. Relationship between prostatic antigen (PSA) and volume of the prostate in benign prostatic hyperplasia in the elderly. Crit Rev Oncol Hematol 2003; 47: 207-211.

[15] Hochberg DA, Armenakas NA, Fracchia JA. Relationship of prostate-specific antigen and prostate volum in patients with biopsy proven benign prostatic hyperplasia. Eur Urol 2003; 44: 695-700.

[16] Di Silverio F,Sciarra A, D Eramo G et al. Relationship among age, prostate specific antigen in men with lower urinary tract symptoms (LUTS) and in different groups of men with and without benign and malignant prostate diseases. Prostate 1998; 36: 1-7.

[17] Jacobson SJ, Jacobson DJ, Girman CJ et al. Natural history of prostatism; risk factors for acute urinary retention. J Urol 1997; 158: 581-487.

[18] Emberton M, Anson K. Acute urinary retention in men: an age old problem. Br Med J 1999; 318: 921-925.

[19] Gustafsson O, Mansour E, Norming U. Prostate -specific antigen (PSA), PSA density and age - adjusted PSA reference values in screening for prostate cancer - a study of a randomly selected population of 2.400 men. Scand J Urol Nephrol 1998; 32: 373-377.

[20] Anjum I, Ahmed M, Azzopardi A et al. Prostatic ifarctonlinfection in acute urinary retention secondary to benign prostatichyperplasia. J Urol 1998; 160: 792-793.

[21] Nadler RB, Humphrey PA, Smith DS. Effect of inflammation and benign prostatic hyperplasia on elevated serum prostate specific antigen levels. J Urol 1995; 154: 407-413. 
[22] Kessler OJ, Keiseri Y, Servadio C et al. Role of chronic inflammation in the promotion of prostatic hyperplasia in rats. J Urol 1998; 159: 1049-53.

[23] Hasui Y, Marutsuka K, Asada Y et al. Relationship between serum prostate specific antigen and histological prostatitis in patients with benign prostatic hyperplasia. Prostate 1994; 25: 91-6.

[24] Powell PH, Smith PJ, Fenely RC. The identification of patients at risk from acute retention. Br J Urol 1980; 52: 520-522.

[25] Klarskov P, Andersen JT, Asmussen CF et al. Symptoms and signs predictive of the voiding pattern after acute urinary retention in men. Scand J Urol Nephrol 1987; 21: 23-8.

[26] Kohnen PW, Drach GW. Pattern in inflammation in prostatic hyperplasia: a histologic and bacteriolog study. J Urol 1979; 121: 755-60.

[27] Irani J, Levillain P,Goujon JM et al. Inflammation in benign prostatic hyperplasia: correlation with prostate specific antigen value. J Urol 1997; 157: 1301-3.

[28] Scattoni V, Raber M, Montorsi F et al. Percent of free serum prostate-specific antigen and histological findings in patients undergoing open prostatectomy for benign prostatic hyperplasia. Eur Urol 1999; 36: 621-30.

[29] Nickel JC, Downey J, Yung I et al. Asymptomatic inflammation and infection in benign prostatic hyperplasia. BJU Int 1999; 84: 976-81.

[30] Berry SJ, Coffey DS, Walsh PC et al. The development of human benign prostatic hyperplasia with age. J Urol 1984; 132: 474-9.

[31] Partin AW, Oesterling JE, Epstein JI et al. Influence of age and endocrine factors an the volume of benign prostatic hyperplasia. J Urol 1991; 145: 405-9.

[32] Collins GN, Lee RJ, McKelvie GB et al.Relationship between prostate specific antigen,prostate volume and age in the benign prostate. Br J Urol 1993; 71: 445-50.

[33] Uygur MC, Erol D, Cetinkaya M et al. Analysis of prostate specific antigen values from 4. 846 Turkish men with symptomatic benign prostatic hyperplasia. The corr elation between prostate-specific antigen and age. Eur Urol 1997; 32: 416-9.

[34] Morote J, Encabo G, Lopez M et al. Prediction of prostate volume based on total and free serum prostate-specific antigen: is it reliable? Eur Urol 2000; 38: 91-5.

[35] Eckhardt MD, Venrooij GE, Boon TA et al. Symptoms and quality of life versus age,prostate volume and urodynamic parameters in 565 strictly selected men with LUTS suggestive of benign prostatic hyperplasia. Urology 2001; 57: 695-700.

[36] Watanabe H. Natural History of benign prostatic hypertrophy. Ultrasound Med Biol 1986; 12: 567-71.

[37] Boyle P, Napakov P. Epidemiology of benign prostatic hyperplasia: current perspectives. Eur Urol 1996; 29 (Suppl 1): 7-11.

[38] Abrams P. New words for old: lower urinary tract symptoms for "prostatism". Br Med J 1994; 308: 929-30.

[39] Abrams P.evalueting lower urinary tract symptoms suggestive of benign prostatic obstruction. Scand J Urol Nephrol Suppl 1999; 203: 1-7.

[40] Richardson TD, Oesterling JE. Age specific reference ranges for serum prostate-specific antigen. Urol Clin North Am 1997; 24: $339-51$.

[41] Hedelin H, Johansson N, Stroberg P. Uneven quality of referrals for lower urinary tract symptoms in men. Lakartidningen 2003; 100: 1435-7.

[42] Lepor H, Machi G. Comparison of the AUA symptom index in unselected males and females between 55 and 79 years of age. Urology 1993; 42: 36-40.

[43] Nickel JC, Effective office management of chronic prostatitis. Urol Clin North Am 1998; 25: 667-84.

[44] Mehik A, Hellstrom P, Lukkarinen A et al. Epidemiology of prostatitis in Finish Men. BJU Int 2000; 86: 443-8. 